\title{
ANALYSIS AND EVALUATION OF THE INFLUENCE OF SELECTED ITS SERVICES ON ROAD TRAFFIC SAFETY AND EFFICIENCY
}

\section{ANALIZA I OCENA WPLYWU WYBRANYCH USEUG ITS NA BEZPIECZEŃSTWO I EFEKTYWNOŚĆ RUCHU DROGOWEGO}

\author{
Agata Kołodziejska, Mirosław Siergiejczyk, Karolina Krzykowska \\ Warsaw University of Technology, Politechnika Warszawska
}

\begin{abstract}
The implementation of Intelligent Transport Systems (ITS) nowadays is associated with a strong need to solve problems related to the high accident rate, as well as low efficiency of transportation process management. The topic of this paper is the characterisation of selected intelligent transport services and the determination of their influence on road traffic safety and efficiency. Two services implemented within the framework of the National Traffic Management System in Poland were distinguished, namely: transmitting information to drivers and incident detection. A general analysis of the relationship between the functioning of ITS services and safety on national roads, as well as traffic efficiency therein was conducted.
\end{abstract}

Keywords: ITS, road information for drivers, incident detection, safety, road traffic efficiency

Streszczenie: $W$ dzisiejszych czasach wdrażanie Inteligentnych Systemów Transportowych (ITS) wiaże sie z silna potrzeba rozwiazywania problemów zwiazanych $z$ wysoka wypadkowościa, a także niska skutecznościa zarzadzania procesami transportowymi. Tematem publikacji jest charakterystyka wybranych ustug inteligentnego transportu oraz określenie ich wpływu na bezpieczeństwo oraz efektywność ruchu drogowego. Wyszczególnione zostały dwie ustugi, wdrażane w ramach Krajowego Systemu Zarzadzania Ruchem w Polsce, a mianowicie ustugi: przekazywania informacji drogowej dla kierowców oraz wykrywania incydentów. Przeprowadzono analizę ogólna powiazania działania danych ustug ITS z bezpieczeństwem na drogach krajowych, a także z efektywnościa ruchu na ich obszarze.

Słowa kluczowe: ITS, informacja drogowa dla kierowców, wykrywanie incydentu, bezpieczeństwo, efektywność ruchu drogowego 
Analysis and evaluation of the influence of selected ITS services on road traffic... Analiza i ocena wptywu wybranych ustug ITS na bezpieczeństwo i efektywność...

\section{Introduction}

The currently increasing demand for transport, as well as the ever-increasing number of vehicles on the road, entails the need to ensure an effective and safe drive from place to place. The terms ITS - Intelligent Transport Systems - was introduced in the second half of the twentieth century and applies to all works, aimed at improving the functioning and the development of the broadly understood transport, through implementing innovative technologies ${ }^{1}$. ITS systems provide a wide range of cutting-edge technologies and devices, which create individual intelligent transport services. Their goal is to increase the mobility and safety of road transport in a given area, but also to decrease its negative impact on the natural environment, traffic volume and the occurrence of road incidents. These systems provide support for drivers and other stakeholders through supplying information on traffic conditions, which are based mainly on real-time measurements. Thanks to such a data flow, it is possible to achieve not only social but also economic and environmental benefits. The deployment of ITS provides for the better usage of both existing road networks and available energy while also helping to curb accidents and improve the efficiency of transport as a whole ${ }^{2}$.

One of the most important topics associated with the issue of commuting on the main roads in Poland is the road traffic safety (RTS) level. It concerns not only the travellers but also the pedestrians and cyclists, using the transport infrastructure in a given area. The high rate of accidents on national roads over the recent years, as well as frequent collisions, are a proof that it is still a burning issue. Due to that fact, this article covers the characteristics of two samples services from the ITS scope, which, if correctly implemented, have a chance of significantly impacting RTS on Polish roads. These services are planned to be implemented in the years 2017-2020, within the framework of the National Traffic Management System (NTMS). Nonetheless, whether an ITS service effectively implements the assumed objectives and whether it supports achieving the intended benefits can be assessed only on the basis of its efficiency indicators.

It is worth noticing that increasing road traffic safety level comes with an increase of the capacity of particular road sections. Adequate traffic management and control, and fast response to undesirable situation significantly increase traffic efficiency. Hence, the probability of a traffic jam at a given road section is minimised, traffic is relieved, thus, the risk of an accident or collision decreases. Therefore, the functioning of particular services from the field of Intelligent Transport Systems need to be considered both, in terms of safety, as well as efficiency of road traffic.

\footnotetext{
1 Chudzikiewicz A.: Inteligentne Systemy Transportowe (ITS) [Intelligent Transport Systems].. Wydział Transportu PW. Stare Jabłonki 2007.

2 Intelligent Transport Systems for Sustainable Mobility. United Nations Economic Commission for Europe. Geneva 2012, http://web.archive.org/web/20151106070216/ http://www.unece.org/fileadmin/DAM/trans/publications/Intelligent_Transport_Systems _for_Sustainable_Mobility.PDF.
} 


\section{Characteristics of selected ITS services}

\section{Transmitting traffic information to drivers}

One of the many ITS services introduced on the Polish roads by the National Traffic Management System is the transmission of road information to the drivers. This service belongs to the category, which includes traffic management, especially on rural roads. Information for travelling users and the means of its provision with a widespread use of ITS measures, play an important role in traffic management systems. ${ }^{3}$ The function of the discussed service comes down to transmitting data about the traffic and the conditions it takes place in (i.a., about road works, occurring events, diversions), about weather conditions, and sometimes about the location of the nearest rest and service areas (RSAs). That information is sent directly to road users, as well as TV networks, radio stations and commercial units, such as portals dealing with travel planning and on-line navigation providers. The information necessary to provide services in the scope of travel planning are created on the basis of data from individual traffic sensors, meteorological sensors and road cameras. They are ultimately passed on to the stakeholders by web sites, the media or through variable message signs (VMS), located directly next to a given road.

The data needed to provide a service of transmitting road data to the drivers are taken from sources such as: spatial database about a road network, traveller information database, visual database, environmental conditions database, maintenance database and RSA/parking database. Whereas, the entities providing specific data to the system are mainly: travellers, road administrators, toll collection system operators and the software of linked road systems. The software cooperating with a given service may include, e.g., traffic management software, incident management software, traffic simulation and forecast management subsystem software, tunnel traffic management software, road maintenance support subsystem software and software for collecting and archiving alphanumeric data, as well as visual data. It also needs to be noted that the functionality of the discussed service is at the operational level. It means that data management and its transmission takes place on a regular basis. Consequently, it is essential that all information necessary to execute a service are transmitted in real-time.

The correct functioning of the discussed service is conditioned on the coordination of its activity with other ITS services offered in the same area. As a result, the services able to cooperate with the transmission of road information to the drivers are as follows:

- a service confirming events and initiating activities,

- a service processing traffic forecast results,

\footnotetext{
${ }^{3}$ Gaca S., Suchorzewski W., Tracz M.: Inżynieria ruchu drogowego. Teoria i Praktyka [Road traffic engineering. Theory and Practice]. WKŁ. Warszawa 2008, 2014
} 
Analysis and evaluation of the influence of selected ITS services on road traffic... Analiza i ocena wptywu wybranych ustug ITS na bezpieczeństwo i efektywność...

- a service managing data regarding traffic on the national road network,

- a service managing traffic speed,

- a service managing traffic lanes,

- a service managing road network spatial database,

- a service managing a database of environmental conditions,

- a service transmitting information about a tunnel to the drivers,

- a service managing a visual database,

- a service managing a maintenance database,

The main aims of implementing a service of transmitting road information include increasing the traffic management efficiency, improving traffic flow, increasing the road safety level, and preventing congestions. The user needs provided by this service are also: increasing the travel comfort, as well as the reduction of exhaust gas emissions to the atmosphere. Nonetheless, an absolute priority in this case, is to increase of trafficability of individual national road section and to shorten the travel time through minimising unnecessary loss of time. Early information regarding the current conditions on the road allows the drivers, inter alia, to adapt the driving speed to the prevailing conditions. It also allows individual road users to avoid travelling through critical places or to smoothly reach a particular rest and service area. This, in turn, leads to meeting the previously mentioned implementation goals.

The service of transmitting information to the drivers was classified by the General Inspectorate for National Roads and Motorways (GDDKiA) as service no. 3.1.2.9: Sharing information about traffic in a road network. Implementation modules for the execution of the discussed service were divided into classes A-I.

Class A modules are used for sharing information about adverse weather conditions and traffic difficulties, such as, e.g., road works. Their role is to decrease the traffic volume on particular section of class A and S national roads before and after a road junction. They can be optionally used on inter-junction sections, however, not less frequently than every $15 \mathrm{~km}$.

Class B implementation modules are used for similar purposes as in the case of the class A module. A shared information about incidents is aimed at decreased the traffic load on national roads before and after important junctions or in the field of the speed and traffic lane control module, as well as on alternatively selected national roads.

Whereas, class $\mathrm{C}$ modules are used only to inform travellers about the current diversion routes. They can be located in the main strings of $\mathrm{A}$ and $\mathrm{S}$ class roads before and after a junction, absolutely in such a way, as to enable changing the route to an alternative one. Apart from that, elements in that class can also be located on specific diversion roads. 


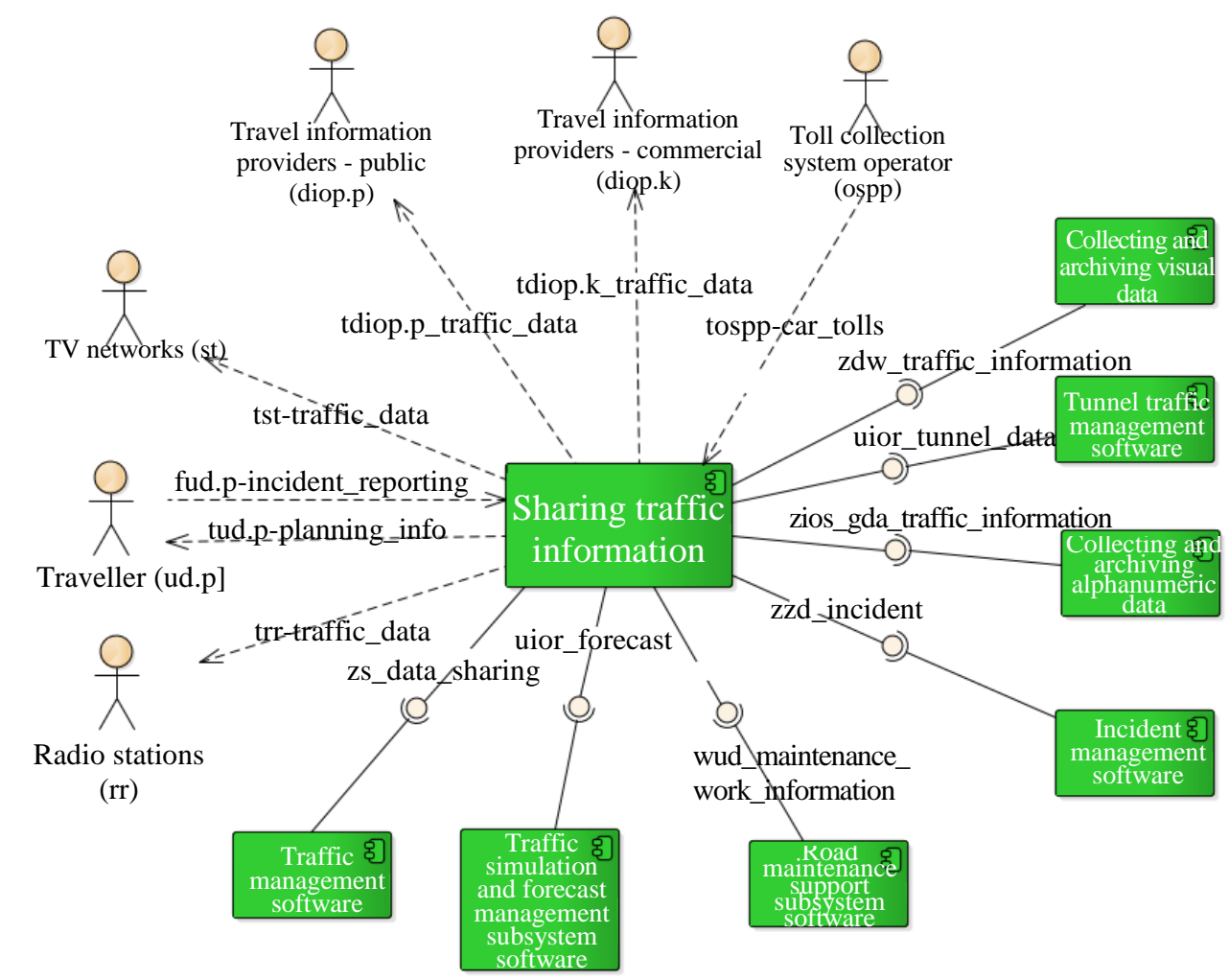

SharingTrafficInformation

Fig. 1 Context diagramof the road traffic information sharing service (source: [NTMS Physical Architecture])

Class D gathers implementation modules informing the drivers about the average travel time for that route, as well as about minimum waiting time at border crossings. Elements of that class are implemented in the main strings of $\mathrm{A}$ and $\mathrm{S}$ class roads, as well as other national roads before a junction or an interchange, and on access roads to cities or in the city centre.

Class E modules are used to inform travellers only about the average waiting time at a specific border crossing. Its modules can be located prior to the nearest RSA/parking. They can also be located immediately before a border crossing; however, it is the case only for truck crossings.

Class $\mathrm{F}$ modules are used in order to provide the travellers with information about the approximate waiting time at many border crossings. The elements in that class can be located before a fork, which enables turning to an alternatively selected border crossing. These devices can also be located before selected RSAs/parking lots. 
Analysis and evaluation of the influence of selected ITS services on road traffic... Analiza i ocena wptywu wybranych ustug ITS na bezpieczeństwo i efektywność...

Class $\mathrm{G}$ modules are used in order to inform about weather conditions at a given location. The devices in this class are located according to the current RTS needs, where meteorological stations are already functioning (class A and S roads, and other national roads).

Whereas, $\mathrm{H}$ class modules are used for informing travellers about occurring incidents, difficulties on the road and subsequently laid out diversions. Information is passed on via radio messages (e.g. CB radio). Modules providing such information can be implemented next to main strings of $\mathrm{A}$ and $\mathrm{S}$ class roads on junctions (about 20-30 km) and larger intersections of national roads.

Implementation modules in the I class are used for informing drivers about temporary difficulties on the roads, occurring incidents and marked out diversions through mobile variable message signs. The vehicles of the administrator of a given road are equipped with such class I devices.

\section{Incident management}

The traffic incident management service involves analysing data about traffic conditions in the network of national roads, with the aim to detect road incidents. Such detection is carried out in order to identify undesirable events and their locations as fast as possible. It is all aimed at restoring proper functionality of the road. Detection of incidents, such as, e.g., collisions or obstacles on the road, starts with analysing data on traffic conditions, analysing data collected from other NTMS devices, as well as video image analysis, etc. Next, identification, as well as classification of the detected road incidents is conducted. In addition, meteorological and traffic data are analysed, in order to check the impact on a given incident. Ultimately, appropriate measures are taken with the aim of mitigating the negative effects of the incident, while all necessary associated information is archived. The end recipients of the discussed ITS service are road administrators, incident managing operator, as well as persons participating in the incident itself.

The data necessary for proper functioning of the service are collected mainly from sources such as CCTV cameras, as well as databases belonging to other ITS functionalities. Whereas, the basic entities providing data for the system mainly include, travellers and the entire road traffic, Crisis Management Centre and rescue services. An important issue in incident management is real-time detection, which means that measurement parameters should be sent without undue delay.

Correct road traffic incident management is associated with cooperation with the following support services:

- a service analysing environmental data and taking actions,

- a service collecting traffic data from the network of national roads,

- traveller interface service for entering incident data,

- operator interface service for incident management,

- a service determining the tunnel status and taking actions,

- a service of Highway Emergency Telephony, 
- a service managing a maintenance database,

- a service managing the conversation database,

- a service supporting winter-time road maintenance.

Whereas, the only service dependent on the incident management service is incident database management.

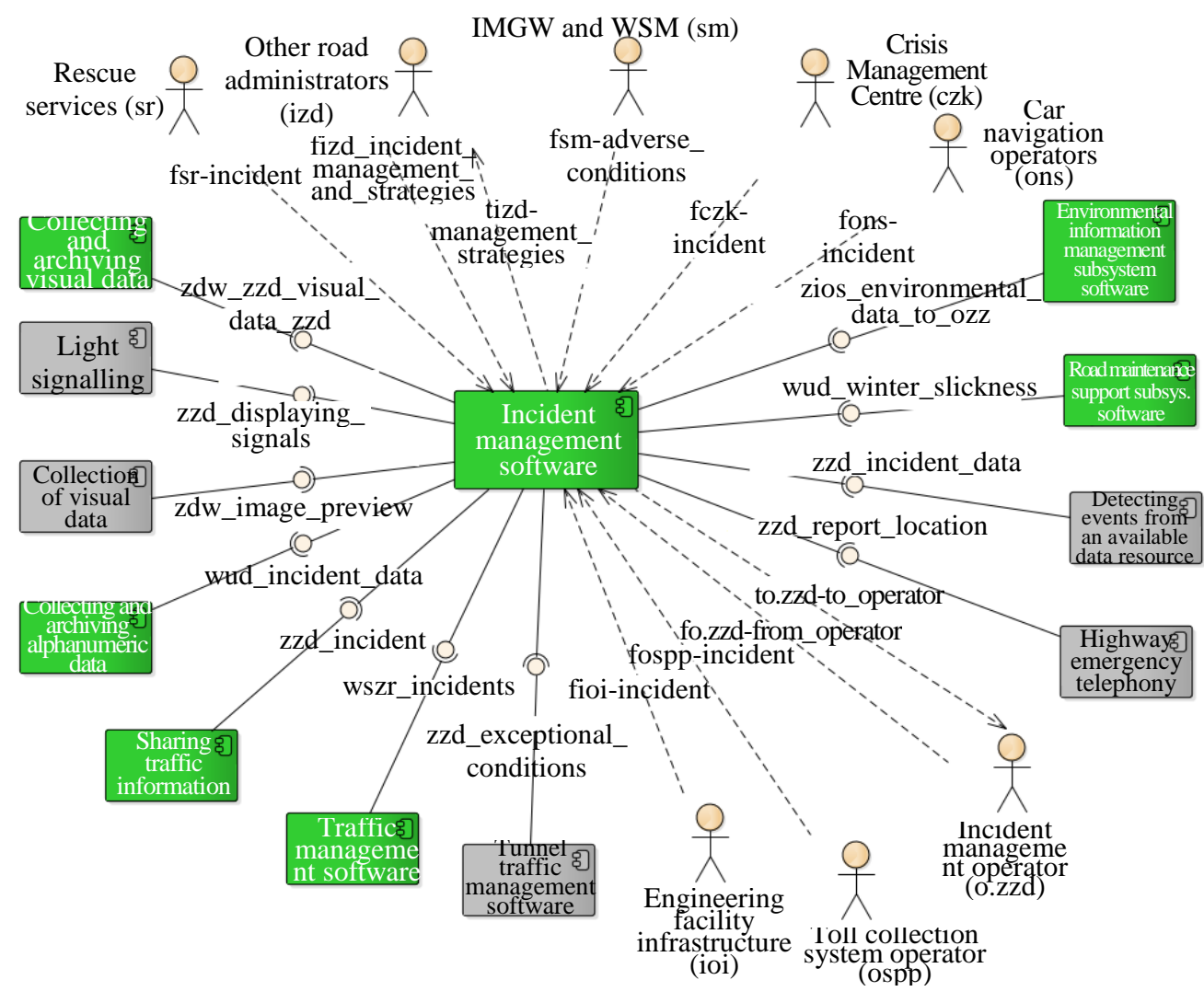

Fig. 2 Context diagram of the incident management service (source: [NTMS Physical Architecture])

The discussed service is aimed at improving national road trafficability (over sections where a road incident happened), traffic management efficiency, as well as increasing traffic safety level. However, the RTS level and preventing congestion are the priorities.

Traffic incident management was divided by GDDKiA into two separate services, namely, no. 3.2.12: Detecting events from an available data resource and 3.2.13: Device identification and classification. Classes of modules executing these services are $\mathrm{A}$ to $\mathrm{F}$.

Class A modules are used only for the detection of vehicles stopped on a freeway, as well as other object, which are obstacles threatening RTS. 
Analysis and evaluation of the influence of selected ITS services on road traffic... Analiza i ocena wptywu wybranych ustug ITS na bezpieczeństwo i efektywność...

The devices in that class can be located within national road intersections, with the exception of A and S class roads. They can also be placed in other locations, with a high road traffic risks caused by frequent vehicle stoppages.

Class B devices are used to detect incidents, such as, e.g. collision, accident, stopped or slow-moving vehicle or a congestion. Incidents of this type are detected thanks to analysing the data from the devices (e.g. counters) functioning within other subsystems. Elements of that class are placed next to single-lane national roads. These modules are attached to the mentioned devices, installed for the purposes of other functionalities.

Class $\mathrm{C}$ devices are implemented with the aim to detect incidents, such as, e.g. a vehicle that stopped, is slow-moving or going upstream, sudden collision or an accident. These incidents may be detected thanks to the analysis of data, which, similarly to class B, come from devices installed for the purposes of other system function. However, modules in this class are attached to such devices, which are installed within dual-lane roads.

Class D devices are used in order to detect vehicles stopped at points, where such stoppages occur on a regular basis. Apart from that, modules in that class can be used for additional applications, such as: detection of vehicles driving upstream, as well as for the detection of road collisions and accidents. Class D elements should be located at points on A and S class roads, where detecting vehicle stoppage is necessary.

On the other hand, class E modules are installed with the aim to detect stoppages of vehicles, objects and even pedestrians, on a road, where such stoppages are too frequent. Upstream driving and sudden changes in traffic free flow are also additionally executed. Elements belonging to class $\mathrm{E}$ are located on $\mathrm{A}$ and $\mathrm{S}$ class roads, usually on deceleration and acceleration lanes, as well as places, with a high risk to RTS.

Class F devices are used for the detection of vehicles, objects and pedestrians stopping on a road. Driving upstream, as well as sudden collisions and accidents in places where they are frequent are additionally detected. Devices of that class should be located similarly to class E, however, taking into account the places with a high probability of a pedestrian intruding the road.

\section{The impact of selected ITS services on the safety and efficiency of road traffic}

\section{Transmitting traffic information to drivers}

Transmitting road information to the drivers needs to be distinguished as one of the most important applications of the ITS technology associated with road traffic safety. The service linked with this application provides an ongoing, unequivocal and uniform information via the use of variable message boards, web sites, as well as CB radio. This service should significantly impact RTS and traffic efficiency, exactly due to the possibility to directly influence the drivers and their road behaviour. 
Most of all, road users informed in advance about occurring incidents, road difficulties and available detours, gain a chance to select an alternative route, as well as to plan a safe trip. In the case of a road collision or accident, traffic is distributed onto other routes, which shall prevent congestion at the incident location. As a result, the capacity in a given area will increase, which, in turn, will have a positive impact on road traffic efficiency. Information transmitted before or during a trip positively impact also individual travel times. This is because the drivers are immediately directed onto detours, while time losses caused by searching for alternative routes are eliminated. In addition, information about road situation (about difficulties, as well as weather conditions) has the chance to increase driver vigilance, which can also make them change the drive speed or style, subsequently, increasing the RTS level. Whereas, in relation to the previously mentioned traffic relief in case of difficulties, it should be noted that decreasing traffic intensity results in a decreased risk of undesirable dangerous situations.

Each of the mentioned impacts on RTS and traffic efficiency depend on the implementation module classes used in a given case. For example, traffic difficulty information modules may improve its efficiency, while weather condition information modules may result in an increase of the road safety level. Nonetheless, the impact of a given service on particular aspects can be evaluated on the basis of its efficiency indicators. In the case of the service of transmitting road information to the drivers, these indicators are: an increased traffic flow, decreasing congestions, shorter travel times and a decrease in accident rates. They make it possible to determine the extent, to which an implemented service impacts the safety and efficiency of the road traffic.

\section{Incident management}

One of the most advanced ITS technologies in Poland is the detection of incidents and failures with the use of image processing algorithms. Such technologies contribute to both, a safer intervention in cases of emergency, as well as volume optimisation through effective traffic management. A service using this technology includes, inter alia, incident detection, assessment and response, mitigation of its unwanted consequences, as well as informing about the incident. It means the different system functionalities are involved in the entire course of that process. For example, automatic vehicle speed control or also, e.g., pedestrian road intrusion detection can be used for incident detection and prevention itself, or at least, mitigation of its negative effects. Due to the coordination of various actions, this service will not only significantly impact traffic efficiency, but also its safety.

The discussed service allows informing relevant emergency services about an incident and its location, resulting in a faster response time. The consequence will be a shorter time of the associated difficulties along a given road section. In addition, it will be possible to almost immediately inform all other road users about the difficulties, which will enable redirecting them to alternative routes.

It will prevent the formation of congestion and the traffic efficiency will increase. Whereas, the impact of the service on RTS is indirect. As previously mentioned, detection of incident on specific roads and classifying them is the basis to initiate actions aimed at informing road users about occurring incidents and redirecting them 
Analysis and evaluation of the influence of selected ITS services on road traffic... Analiza i ocena wplywu wybranych ustug ITS na bezpieczeństwo i efektywność...

onto other routes. Therefore, it decreases the risk of subsequent, dangerous situations. It is also worth noticing that incident data are archived, which makes it possible to analyse them and determine locations with increased risk. Keeping statistics regarding this issue has the potential to facilitate preventive actions and increase the safety in individual areas.

Whereas, the impact of the incident management service and its particular implementation modules on the efficiency RTS can be evaluated on the basis of individual service efficiency indicators. In the case of the discussed service, these are: an increase in traffic flow, decreasing congestions, a decrease in accident rates, as well as shortening the travel time of emergency services to the incident location. For example, a decrease in the number of congestions after implementing a service shows its positive influence on road traffic efficiency.

\section{Conclusions}

This article approached the issue of road traffic safety and efficiency, as well as the possibilities to improve them using selected ITS services. Two specific services in the field of intelligent transport were presented, namely, transmitting road information to drivers and incident management.

It can be concluded that the service of transmitting information to the drivers directly impacts both, the RTS, as well as traffic efficiency. Depending on the used implementation modules, the assessment of their impact on the mentioned aspects is possible. Whereas, the efficiency indicators of that service can provide some information about its actual impact on the traffic on national roads. On the basis of the conducted potential impact analysis it can be evaluated that the correct implementation of devices executed a particular ITS service has the chance to increase the safety level and positively impact the traffic flow on a given road.

On the other hand, the incident management service impacts the improvement of traffic conditions directly and the RTS indirectly. It is associated with the previously discussed service of informing the drivers. Transmitting incident information to road users prevents excessive traffic volume on a given road, thus, making the drive safer. Therefore, it can be concluded that the implementation of the incident management service, together with the transmission of road information has a chance to not only increase traffic efficiency but also improve its safety.

On the basis of the conducted analysis, it can be concluded that the implementation of the discussed ITS services on national roads is justified. Such solutions would generate benefits in the RTS scope, as well as traffic management efficiency. This is why ITS services need to be treated as the main tools for the improvement of these aspects.

However, we need to bear in mind the fact that the impact efficiency of the discussed services depends also on the correctness of planning, arrangement and configuration of individual modules. It means that they need to be adapted to the needs generated in a given area. Solution incorrectly matched to the demand will not significantly impact the improvement of the considered road traffic safety and efficiency aspects.

The publication has been prepared within the framework of the project Development of Road Innovations funded by the National Centre for Research and Development and the General Directorate for National Roads and Motorways (Contract No. DZP/RID-I41/7/NCBR/2016). 


\section{Literature}

[1] Adamski A.: Inteligentne Systemy Transportowe: sterowanie, nadzór i zarządzanie. [Intelligent Transport Systems: control, supervision and management].AGH. Kraków 2003, pp: 1-10

[2] Architektura Fizyczna KSZR [NTMS Physical Architecture], http://www.kszr.gddkia.gov.pl/index.php/pl/do-pobrania/materialy-robocze

[3] Architektura Funkcjonalna KSZR [NTMS Functional Architecture], http://www.kszr.gddkia.gov.pl/images/Architektura_KSZR/architektura_funkcjon alna_KSZR_-_1.1.pdf

[4] Chudzikiewicz A.: Inteligentne Systemy Transportowe (ITS) [Intelligent Transport Systems]. Wydział Transportu PW. Stare Jabłonki 2007, pp.: 1-4, 9-11

[5] Gaca S., Suchorzewski W., Tracz M.: Inżynieria ruchu drogowego. Teoria i Praktyka [Road traffic engineering. Theory and Practice]. WKŁ. Warszawa 2008, 2014, pp.: 361-369, 434-437

[6] Intelligent Transport Systems for Sustainable Mobility. United Nations Economic Commission for Europe. Geneva 2012, http://web.archive.org/web/20151106070216/ http://www.unece.org/fileadmin/DAM/trans/publications/Intelligent_Transport_Systems_ for_Sustainable_Mobility.PDF

[7] Raport o stanie bezpieczeństwa ruchu drogowego dla dróg krajowych w zarządzie GDDKiA, [Report on the road traffic safety status of national roads administered by GDDKiA] https://www.gddkia.gov.pl/pl/1232/wypadki-na-drogach-krajowych

[8] Raport z realizacji zadania 2 projektu RID 4D: Pogłębienie studiów analizy w zakresie wykorzystania usług ITS w celu poprawy stanu BRD i efektywności ruchu. [Implementation report for task 2 of the RID 4D project: In-depth analysis studies in the scope of using ITS services in order to improve the RTS status and traffic efficiency]

[9] Safety Applications of Intelligent Transportation Systems in Europe and Japan. Office of International Programs. Washington 2006, s: 3-35

[10] Tabele klas modułów wdrożeniowych [Implementation module class tables], http://www.kszr.gddkia.gov.pl/images/Architektura_KSZR/Arch_fizyczna/Klasy_Mod_Wdroz.pdf

[11] Łubkowski, P. \& Laskowski, D. 2015. Selected issues of reliable identification of object in transport systems using video monitoring services. In Communication in Computer and Information Science, vol. 471: 59-68. Berlin Heidelberg: Springer.

[12] Paś, J. 2015a. Selected methods for increases reliability the of electronic systems security. Journal of KONBiN 3(35)2015: 147-156.

[13] Siergiejczyk M., Rosiński A., Dziula P., Krzykowska K., Reliability-Exploitation Analysis of Highway Transport Telematics Systems, Journal of KONBiN 1(33) 2015 ISSN 1895-8281, DOI 10.1515/jok-2015-015, s. 177-186.

[14] Siergiejczyk M., Rosiński A., Krzykowska K., Reliability-exploitation analysis of the alarm columns of highway emergency communication system, Journal of KONBiN 2(38)2016, ISSN 1895-8281, pp. 53-76.

[15] Stawowy M. 2010. Reliability of data obtained from video systems of traffic surveillance. Archives of Transport System Telematics. PSTT, pp. 46-51. 
Analysis and evaluation of the influence of selected ITS services on road traffic... Analiza i ocena wplywu wybranych ustug ITS na bezpieczeństwo i efektywność...

[16] Zając M., Świeboda J. 2015. Process hazard analysis of the selected process in intermodal transport. International Conference on Military Technologies (ICMT). IEEE, pp. 1-7.

[17] Chowdhury M. A., Sadek A. 2003. Fundamentals of Intelligent Transportation Systems Planning. Artech House ITS Library. Boston, London.

[18] Ehlers U.C., Ryeng E.O., McCormack E., Khan F., Ehlers S. 2017. Assessing the safety effects of cooperative intelligent transport systems: A bowtie analysis approach. Accident Analysis and Prevention 99(2017). Elseview, pp. 125 - 141.

[19] Parallos A., Hernandez - Jayo U., Onieva E., Garcia Zuazola I.J. 2015. Intelligent Transport Systems: Technologies and Applications. Wiley, ISBN: 978-1-11889478-1.

[20] Małecki K., Iwan S., Kijewska K. 2014. Influence of Intelligent Transportation Systems on reduction of the environmental negative impact of urban freight transport based on Szczecin example. Procedia - Social and Behavioral Sciences 151 (2014). Elsevier, pp. 215 - 229.

[21] Zhuhadar L., Thrasher E., Marklin S., Ordonez de Pablos P. 2017. The next wave of innovation - Review of smart cities intelligent operation systems. Computers in Human Behavior 66 (2017). Elsevier, pp. 273 - 281.

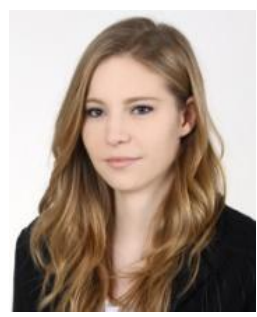

Agata Kolodziejska, BSc. - a master's student at the Department of Transport at the Warsaw University of Technology, specialising in Intelligent Transport Systems. She obtained the Engineer's title at the same university, specialising in Transporation Telematics. (Share 33,3\%)

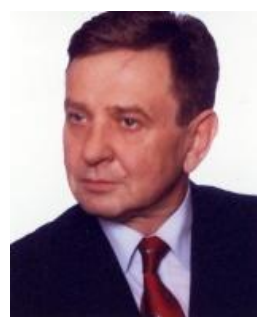

Prof. Miroslaw Siergiejczyk, PhD. Eng. - scientific fields of interest of the paper co-author concern among other issues of architecture and services provided by telecommunications networks and systems, especially from perspective of their applications in transport, reliability and operation of telecommunications networks and systems, modelling, designing and organising telecommunications systems for transport. (Share $33,3 \%)$

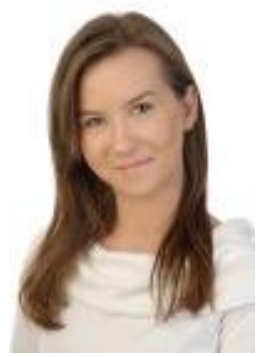

Karolina Krzykowska, MSc. Eng. - in research co-author of the article deals mainly with considerations on the reliability analysis of intelligent transport systems in the branch of road transport and aviation. She has several publications on this subject. (Share 33,3\%) 